\title{
A NEW BEE OF THE GENUS COLLETES FROM PANAMA
}

\author{
By Myron HaRmon SWENK \\ University of Nebraska, Lincoln, Neb.
}

In a lot of bees of the genus Colletes belonging to the British Museum, I found a well-marked new species, which may be described as follows:

Colletes isthmicus sp. nov.

․ Length $8 \mathrm{~mm}$. Black. Head nearly one-third wider than long $(57 \times 75)$, the distance between the lower orbits only slightly (about one-tenth) less than the interorbital space on the vertex $(42: 38)$. Clypeus shining, convex with a median feebly sulcate area, coarsely striate-punctate except just before the apical margin which is smoothish, slightly reflexed and feebly medially emarginate. Supraclypeus shiny, coarsely and closely punctured except on a small, median, impunctate spot. Face dullish, densely and shallowly, rather finely punctured, the foveæ short and narrow, scarcely encroaching on the vertex, but the smooth, dullish internal portion crossing the depressed sides of the vertex as an impunctate band contiguous to the orbital summits. Vertex about ocelli shiny, finely and rather closely punctured, elevated. Cheeks shiny, sparsely indistinctly punctured, thinly clothed with simple, white hairs posteriorly. Malar space minutely lined, about one-third as long as wide or nearly that $(3 \times 10)$. Pubescence of face thin, very short, minutely plumose and grayish white in color, with longer, finely plumose, erect, sparse black hairs intermixed below the antennal level, the edges of the clypeus and supraclypeus with mixed black and yellowish, simple, suberect hairs, the clypeus nearly bare, its sparse hairs like those on its margins only shorter. Vertex with mixed black and whitish, thin, erect, plumose hairs, occiput 
with a copious, white fringe. Antennæ short, clavate, black with the under side of the flagellum slightly tinged with brownish, joint 3 slightly longer than 2 or 4 , which are subequal, the proportion of joints 2-5 being $4.5: 5: 4.5: 4.5$, the median flagellar joints one-sixth shorter than wide $(5 \times 6)$. Prothoracic spines very short but sharp, entirely concealed in the pubescence. Mesoscutum with rather coarse but not very deep punctures, separated the width of one or almost so anteriorly and laterally, on the posterior disk a distinctly defined, rather large, polished and impunctate area, the parapsidal furrows also bounded by impunctate lines. Mesoscutellum basally and medially polished and impunctate, laterally coarsely and rather closely punctured, the punctures crowded along the apical margin. Metanotum roughened by coarse, shallow, cancellate punctures. Superior face of the propodeum very broad and well defined, its apical margin strongly rimmed, divided by a few straight striæ into a few large, rectangular, shiny pits nearly as wide as long medially. Enclosure on the posterior face of the propodeum funnel-shaped, mostly smooth and polished, a few oblique striæ at extreme sides basally and indications of a short, basal median carina, the downward prolongation moderately broad at base. Surrounding areas of propodeum shiny, very coarsely reticulated. Mesopleura with coarse, round punctures about like those on mesoscutum anteriorly. Pubescence of mesopleura discally long, thin, erect, plumose and black, forming two longer and denser black tufts under and before the tegulæ, the space between these tufts with a contrasting, shorter, finely plumose, almost pollinose, snowy white hair-tuft, the mesoscutum with a short, plumose, mixed black and grayish white pubescence that is rather dense marginally but very thin discally, the pale hairs preponderating and forming an unmixed fringe along proscutal-mesoscutal suture, the mesoscutellum with copious, long, wholly black, plumose hairs with a contrasting snowy white axillary tuft of short hairs and a narrow fringe of similar hairs in the mesoscutal-mesoscutellar suture, the metanotum and propodeum with long, copious, erect, plumose, grayish white hairs, these very thinly mixed with dark ones on the sides of the posterior face of the propodeum. Tegulæ shining 
piceous. Wings hyaline basally, slightly darkened on the apical margin and in the marginal cell, nervures and stigma dark brown, second submarginal cell above slightly wider than the third. Anterior coxæ simple. Tarsal claws red, deeply medially toothed. Tibial spurs dark, the anterior one finely pectinate. Hind basitarsi three times as long as wide $(25 \times 8)$. Hind legs with the coxæ, trochanters and inferior base of the femora whitish-haired, the femora above and at apex black-haired, the tibial hairs almost all black, especially the long-plumose hairs on the anterior face, the basitarsi with pale yellowish hair within but black bristles externally, the intermediate legs with mostly pale hairs but black-haired on tibiæ and basitarsi externally, the anterior legs pale-haired and with yellowish hair on the tarsi. Abdomen neatly conical, polished, basal tergite impunctate, tergite 2 minutely and indistinctly punctured. Apical margins of the tergites (1-5) broadly but feebly depressed and covered with a loose, minute pile to form broad, pale yellowish fasciæ. Basal tergite with very thin, erect, white hair, tergites 2 and 3 with a minute, thin, black pile, tergites 4-6 with a longer black pile and numerous long, black bristles. Venter finely, indistinctly punctured and minutely reticulated, sternite 6 toward apex finely rugose and with crescentic, shallow, lateral fossæ on each side of the median line.

i. Length 6-7 mm. Distinctly smaller and more slender than the $\%$. Head sub-triangular, about three-tenths wider than long $(50 \times 65)$ and the face narrowing about onefourth between the vertex and the lower orbital margins $(39: 20)$. Sculpture of clypeus, supraclypeus and face as in the $q$, but pubescence longer and more copious with the black hairs below antennal level much more numerous and the pale ones tinged with yellowish. Depressed sides of the vertex impunctate or very feebly punctured, the elevated area very slightly black-haired. Malar space of the same length as in the $q$ but much less wide so that it is nearly one-half as long as wide $(3 \times 6.5)$. Antennæ long, slender, black with the flagellum obscurely brownish beneath, joint 3 shorter than 4 or following, the proportion of joints $2-5$ being $3.5: 5: 6.5: 7.5$, the median flagellar joints about one and two-fifths as long as wide (7.5 x 5.5). Meso- 
scutum and mesopleura much less coarsely punctured than in the $q$, and the punctures separated about twice the width of one, the mesoscutellum with the posterior punctures not crowded; otherwise the thoracic sculpture as in the $q$. Thoracic pubescence yellowish white, short and thin and very feebly intermixed with blackish on the mesoscutellum, mesoscutellar hairs long and mostly blackish, hair of metanotum, propodeum and mesopleura long and thin, the latter region with a few blackish hairs intermixed. Wings rather less darkened apically than in the $q$, otherwise similar. Tarsal claws sub-apically cleft, the apical tarsal joint sometimes reddish. Tibial spurs not obviously pectinate. Hind basitarsi proportioned as in the $ᄋ$ (21 x 7), the intermediate one about twice as long as wide ( $I I=4.5 \times 8.5)$. Hair of legs all pale. Abdomen elongate conical, polished, basal tergite minutely punctured, the punctures separated several times the width of one, following tergites very finely, indistinctly punctured. Apical margins of the tergites more distinctly depressed than in the $q$, the fasciæ whitish and on tergites 1-5. Pubescence of the tergum much as in the $\circ$. Apical margins of the sternites with a dense, narrow, apical fringe, longest laterally, forming distinct hair bands. Sternite 6 apically smooth and shining, slightly concave, medio-basally slightly elevated, without distinctive sculpture.

Type Locality_San Lorenzo, Chiriqui, Panama.

Type-A female collected by Mr. Champion. In the collection of the British Muesum.

Allotype-A male from the type lot. In the collection of the British Museum.

Remarks-This species is easily recognizable by the black hair of the mesopleura and posterior legs, impunctate first tergite, short malar space and small size, in the $q$. It is closest, probably, to $C$. mexicanus Cresson. The above measurements are of the type and allotype.

Specimens Examined-Total number 9 (2우, 7 o $\hat{o})$, from localities as follows: Panama: San Lorenzo, 9. 

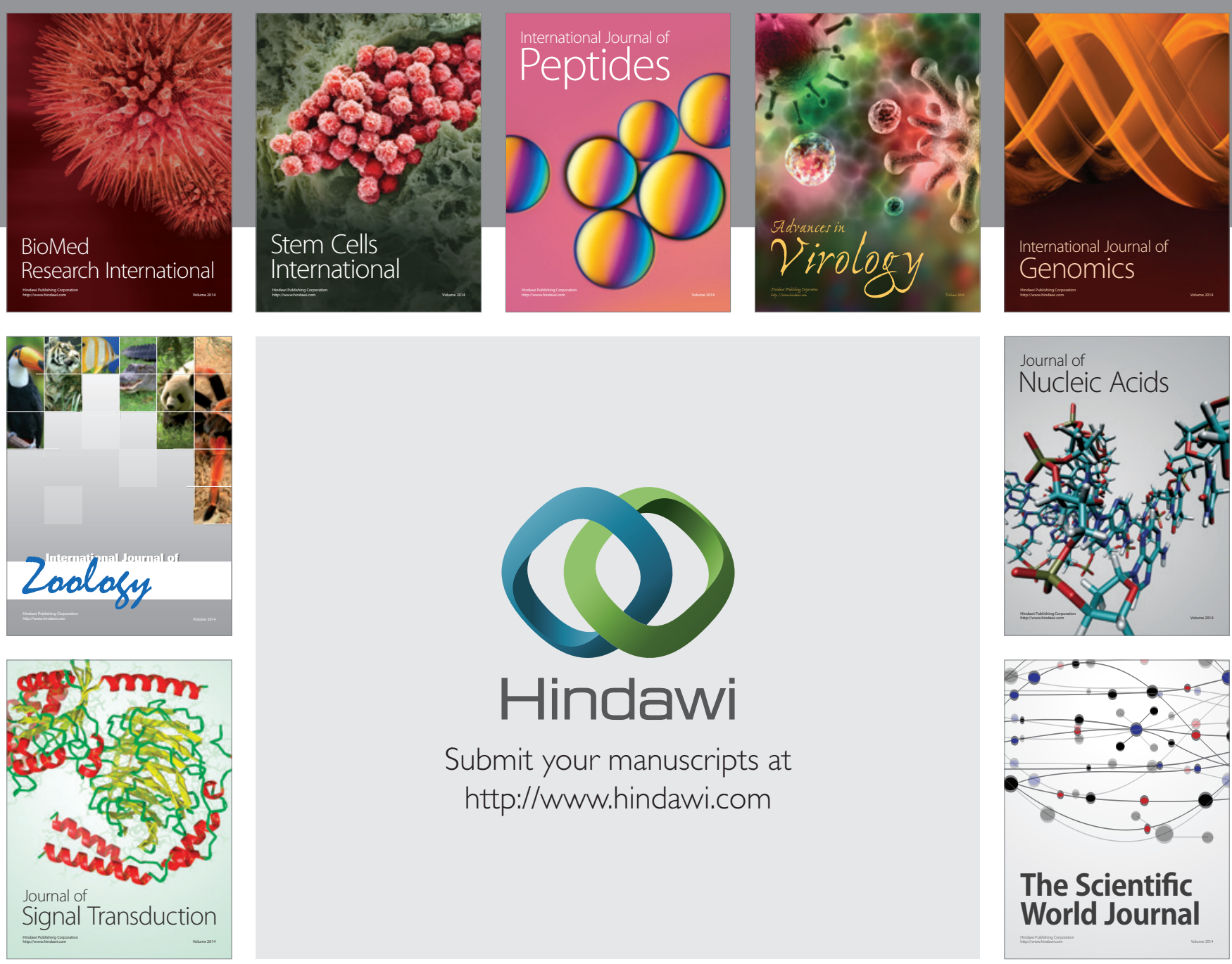

Submit your manuscripts at

http://www.hindawi.com
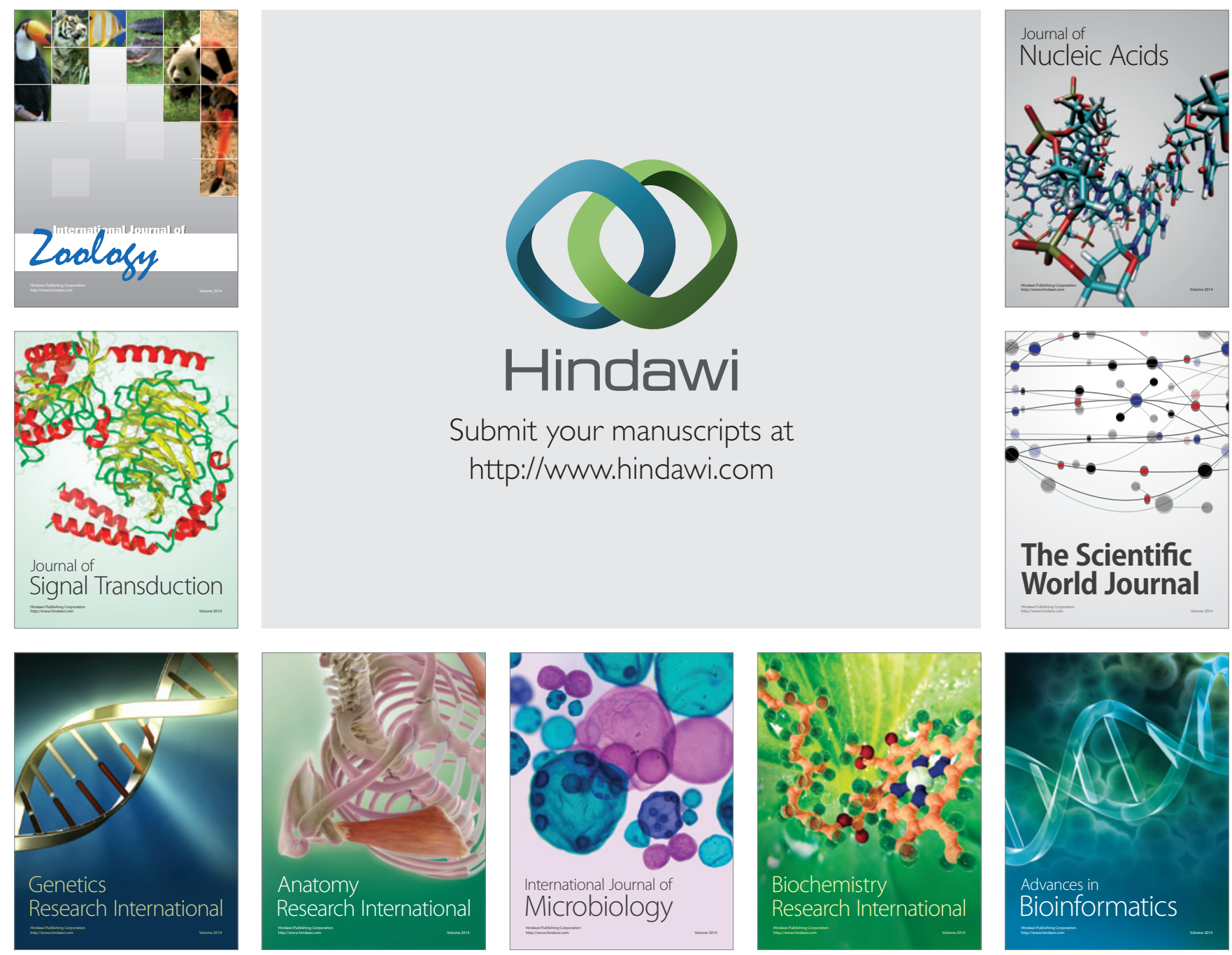

The Scientific World Journal
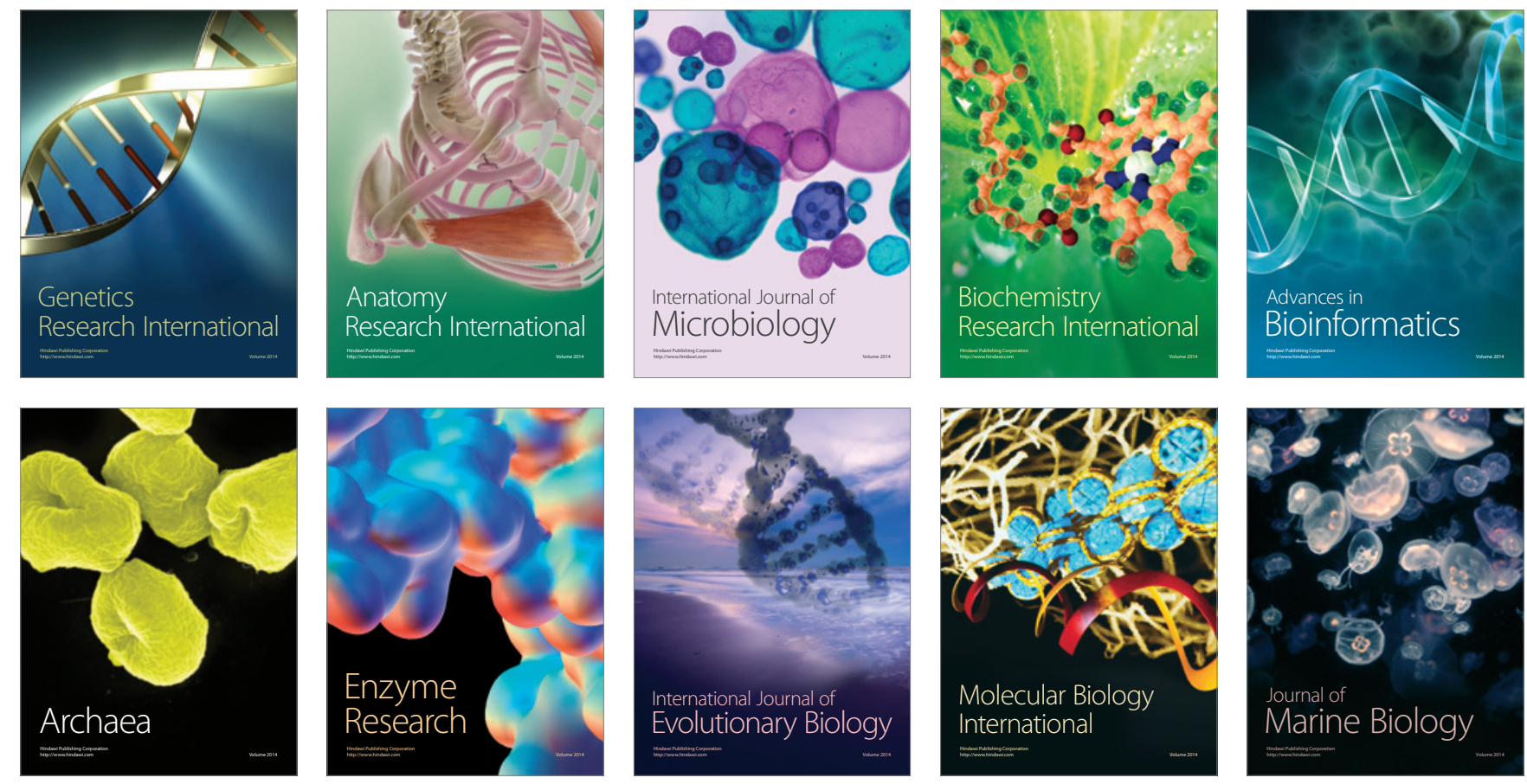